\title{
Anti-CAR-engineered T cells for epitope-based elimination of autologous CAR T cells
}

\author{
Stefanie Koristka ${ }^{1} \cdot$ Pauline Ziller-Walter $^{2} \cdot$ Ralf Bergmann $^{1} \cdot$ Claudia Arndt $^{1} \cdot$ Anja Feldmann $^{1} \cdot$ Alexandra Kegler $^{1}$. \\ Marc Cartellieri $^{3} \cdot$ Armin Ehninger $^{4} \cdot$ Gerhard Ehninger $^{3,4} \cdot$ Martin Bornhäuser $^{5,6,7} \cdot$ Michael P. Bachmann $^{1,2,6,7}$ (B)
}

Received: 1 September 2018 / Accepted: 7 August 2019 / Published online: 14 August 2019

(c) The Author(s) 2019

\begin{abstract}
Although CAR T-cell therapy has demonstrated tremendous clinical efficacy especially in hematological malignancies, severe treatment-associated toxicities still compromise the widespread application of this innovative technology. Therefore, developing novel approaches to abrogate CAR T-cell-mediated side effects is of great relevance. Several promising strategies pursue the selective antibody-based depletion of adoptively transferred T cells via elimination markers. However, given the limited half-life and tissue penetration, dependence on the patients' immune system and on-target/off-side effects of proposed monoclonal antibodies, we sought to exploit $\alpha \mathrm{CAR}$-engineered $\mathrm{T}$ cells to efficiently eliminate CAR T cells. For comprehensive and specific recognition, a small peptide epitope (E-tag) was incorporated into the extracellular spacer region of CAR constructs. We provide first proof-of-concept for targeting this epitope by $\alpha \mathrm{E}$-tag CAR T cells, allowing an effective killing of autologous E-tagged CAR T cells both in vitro and in vivo whilst sparing cells lacking the E-tag. In addition to CAR T-cell cytotoxicity, the $\alpha$ E-tag-specific T cells can be empowered with cancer-fighting ability in case of relapse, hence, have versatile utility. Our proposed methodology can most probably be implemented in CAR T-cell therapies regardless of the targeted tumor antigen aiding in improving overall safety and survival control of highly potent gene-modified cells.
\end{abstract}

Keywords Chimeric antigen receptor $\cdot$ Immunotherapy $\cdot$ Toxicity management $\cdot$ Elimination tag

$\begin{array}{ll}\text { Abbreviations } \\ \text { ADCC } & \text { Antibody-dependent cellular cytotoxicity } \\ \text { CDC } & \text { Complement-dependent cytotoxicity } \\ \text { CHO } & \text { Chinese hamster ovary } \\ \text { EGFP } & \text { Enhanced green fluorescent protein } \\ \text { E-tag } & \text { Peptide epitope E7B6 } \\ \text { GzmA } & \text { Granzyme A }\end{array}$

Electronic supplementary material The online version of this article (https://doi.org/10.1007/s00262-019-02376-y) contains supplementary material, which is available to authorized users.

Michael P. Bachmann

M.Bachmann@hzdr.de

1 Department of Radioimmunology, Institute of Radiopharmaceutical Cancer Research, HelmholtzZentrum Dresden-Rossendorf (HZDR), Bautzner Landstraße 400, 01328 Dresden, Germany

2 Tumor Immunology, University Cancer Center (UCC), 'Carl Gustav Carus' Technische Universität Dresden, Fetscherstraße 74, 01307 Dresden, Germany

3 Cellex Patient Treatment GmbH, Tatzberg 47, 01307 Dresden, Germany
GzmB Granzyme B

HEK293T Human embryonic kidney cell line

Luc Firefly luciferase

MFI Median fluorescence intensity

Orf Open reading frame

PSCA Prostate stem cell antigen

TM Targeting module

UniCAR Universal chimeric antigen receptor
4 GEMoaB Monoclonals GmbH, Tatzberg 47, 01307 Dresden, Germany

5 Medical Clinic and Policlinic I, University Hospital 'Carl Gustav Carus' Technische Universität Dresden, Fetscherstraße 74, 01307 Dresden, Germany

6 German Cancer Consortium (DKTK), partner site Dresden, and German Cancer Research Center (DKFZ), Heidelberg, Germany

7 National Center for Tumor Diseases (NCT), 'Carl Gustav Carus' Technische Universität Dresden, Dresden, Germany 


$\begin{array}{ll}V_{\mathrm{H}} & \begin{array}{l}\text { Variable domain of the heavy chain of a } \\ \text { monoclonal antibody }\end{array} \\ V_{\mathrm{L}} & \begin{array}{l}\text { Variable domain of the light chain of a mono- } \\ \text { clonal antibody }\end{array}\end{array}$

\section{Introduction}

Within the last decades, the tremendous progress in genetic engineering paved the way for generating CAR T cells. CARs typically comprise an extracellular antigen recognition moiety fused via a flexible hinge and transmembrane region to an intracellular signaling unit, thereby combining the virtues of Abs (high antigen-binding specificity) and immune cells (potent anti-tumor effector mechanisms) within one single fusion molecule [1]. Especially for the treatment of relapsed/refractory B-cell-derived malignancies, CAR T-cell therapy targeting the CD19 antigen has achieved remarkable clinical results [2-6].

However, severe treatment-associated toxicities still restrain the widespread application of this promising technology. The most frequent side effects following CAR T-cell administration include cytokine release syndrome [4-7], neurotoxicity [6, 7], on-target/off-tumor responses [4, 8-10], and anaphylaxis [11], all of which may lead to lifethreatening or even fatal implications. Given the enormously long-term persistence and proliferative capacity of genetically engineered T cells [12], control and reversal of toxicity have emerged as important aspects of CAR T-cell therapy.

Various approaches have been pursued to mitigate side effects ranging from global, unspecific immunosuppression to selective ablation of CAR-engineered $\mathrm{T}$ cells. The latter strategy is currently under massive investigation and is based on the transgenic introduction of either suicide genes or elimination marker genes. Two well-studied suicide genes are herpes simplex virus thymidine kinase [13] and inducible caspase-9 [14-16] which can be triggered by the administration of small molecules to effectively induce CAR T-cell death. Alternatively, forced expression of a targetable cellsurface antigen physiologically not present on T lymphocytes has been evaluated. Proposed elimination markers are truncated EGFR $[17,18]$ and CD20 $[19,20]$ which are recognized by the mAbs cetuximab and rituximab, respectively. Infusion of these therapeutic molecules subsequently results in specific CAR T-cell depletion via antibody-dependent cellular cytotoxicity (ADCC) and complement-dependent cytotoxicity (CDC).

Although all of the above-mentioned methodologies allow the effective elimination of adoptively transferred $\mathrm{T}$ cells in case of severe toxicities, each approach exhibits distinct limitations potentially restricting a broad clinical utility. These include immunogenicity [21], large size of the proposed depletion marker (over $130 \mathrm{aa}$ ), dependence on the patients' immune system (ADCC, CDC) and occurrence of on-target adverse events due to $\mathrm{mAb}$ recognition of healthy tissue [22]. Moreover, all techniques are based on the insertion of an additional gene that is co-expressed with the CAR of interest, bearing the risk of CAR T-cell escape in case the safety switch is not uniformly and/or stably expressed. Therefore, we intended to use a short peptide epitope (E-tag) directly incorporated into the CAR architecture as a targetable moiety for selective and stringent CAR T-cell elimination [23, 24]. Another substantial drawback of currently available safeguard strategies is their reliance on pharmacological drugs whose therapeutic effect inevitably declines due to their short half-life. For that reason, we sought to use $\mathrm{T}$ lymphocytes as living drugs that are equipped with a CAR construct directed against a targetable portion of the therapeutic CAR. In this report, we demonstrate the utility of the E-tag as a selection marker for an efficient T-cell-mediated elimination of autologous CAR T cells.

\section{Materials and methods}

\section{Cell lines and culture}

All cell lines were kept at $37^{\circ} \mathrm{C}$ in a humidified atmosphere of $5 \% \mathrm{CO}_{2}$. PC3 cells were stably transduced with the open reading frame (orf) encoding the prostate stem cell antigen (PSCA) as previously reported [25]. The murine fibroblast cell line 3T3 and the human embryonic kidney cell line HEK293T were culture in DMEM (ThermoFisher Scientific, Schwerte, Germany) supplemented with $10 \%$ FCS, $100 \mu \mathrm{g} / \mathrm{ml}$ penicillin/streptomycin and $1 \%$ non-essential aa. PC3-PSCA and Chinese hamster ovary (CHO) cells were maintained in RPMI 1640 media supplemented with $10 \%$ FCS, $100 \mu \mathrm{g} / \mathrm{ml}$ penicillin/streptomycin, $1 \%$ nonessential aa, $1 \mathrm{mM}$ sodium pyruvate and $2 \mathrm{mM} N$-acetylL-alanyl-L-glutamine (all purchased from Biochrom, Berlin, Germany).

\section{Generation of CAR vectors}

Cloning and structural composition of conventional CARs as well as the universal chimeric antigen receptor (UniCAR) $28 / \zeta$ construct have been described previously in detail [23, $24,26]$. Briefly, they contain an extracellular binding moiety derived from the $\alpha$ PSCA MB1 mAb [25], the $\alpha C D 19$ HD37 $\mathrm{mAb}$ [27] or the $\alpha \mathrm{La} 5 \mathrm{~B} 9 \mathrm{mAb}$ [28] followed by hinge and transmembrane domain of human CD28 and cytoplasmic activation domains of $\mathrm{CD} 28$ and $\mathrm{CD} 3 \zeta$. As a targetable moiety, the peptide epitope E7B6 (E-tag) is incorporated in the extracellular spacer region. The Stop variant of the UniCAR 
lacks intracellular sequences downstream of the CD28 transmembrane domain.

To generate a UniCAR lacking the E-tag, the DNA fragment coding for the extracellular part of the CAR $28 / \zeta$ was cut out of the respective vector with SfiI and HpaI. A DNA sequence encoding the $\mathrm{scFv} 5 \mathrm{~B} 9$ and hinge region without the E7B6 tag was synthesized by Eurofins Genomics (Ebersberg, Germany) and cloned via SfiI and HpaI into the expression vector p6NST60-CAR $28 / \zeta$, generating the $\triangle$ CAR $28 / \zeta$ construct.

The novel $\alpha$ E-tag CAR $28 / \zeta$ was obtained as follows: first, a fragment encoding the antigen-binding domain was generated by cutting the sequence of the humanized $\mathrm{scFv}$ La (7B6) $V_{\mathrm{L}}-V_{\mathrm{H}}$ out of a pSecTag2B vector with NheI and ApaI. The orf of a fragment containing the hinge, transmembrane and signaling domain of human CD28 as well as human $\mathrm{CD} 3 \zeta$ signaling chain was cut out of a cloning vector available in our lab using the restriction enzymes MssI and ApaI. Finally, the expression vector p6NST60-MCS was digested with $\mathrm{XbaI} / \mathrm{Ksp \textrm {AI }}$ and ligated with the aforementioned two fragments resulting in the vector p6NST60-hu

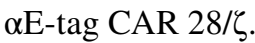

The Orf of all CAR constructs was C-terminally fused to the DNA sequence coding for enhanced green fluorescent protein (EGFP). To allow for a co-translation of CAR and EGFP from one mRNA, both reading frames are separated by a $2 \mathrm{~A}$ 'cleavage' site derived from Thosea asigna virus that induces a ribosomal 'skip' from one codon to the next without the formation of a peptide bond [29].

\section{Production and purification of aPSCA targeting modules (TMs)}

Design, cloning, and purification of $\alpha$ PSCA-E5B9 TM from $3 \mathrm{~T} 3$ cell culture supernatants was previously described in detail $[25,30]$. For redirection of $\alpha E$-tag CAR $T$ cells, murine or humanized $\alpha$ PSCA scFvs (clone MB1) were C-terminally modified to contain the E7B6 epitope (E-tag). The respective orfs were cloned into the p6NST50 vector which was used to generate a stable $\mathrm{CHO}$ cell line for permanent TM production. Purification from cell culture supernatants and analysis of protein concentration were conducted as reported elsewhere [25, 30, 31].

\section{Isolation, transduction, and expansion of human primary $\mathrm{T}$ cells}

Buffy coats were supplied by German Red Cross (Dresden, Germany). Human $\mathrm{CD}^{+}, \mathrm{CD}^{+}$or $\mathrm{CD}^{+}{ }^{+} \mathrm{T}$ cells were isolated and cultured as described previously $[25,28,30,31]$.

Production of lentiviral particles using HEK293T cells and T-cell transduction was conducted as reported elsewhere $[23,26,32]$. In brief, $T$ cells were stimulated using $\alpha \mathrm{CD} 3 /$
CD28 DynaBeads ${ }^{\circledR}$ (Invitrogen, ThermoFisher Scientific) at a 1:4 bead to cell ratio. For T-cell transduction concentrated virus supernatant was added five times within the first 3 days of expansion. After successful genetic modification verified by EGFP expression, cells were sorted on a FACSAria III (BD Biosciences Pharmingen, Heidelberg, Germany). One day prior to experiments, $T$ cells were rested in complete RPMI 1640 lacking any recombinant cytokines.

\section{Flow cytometric analysis}

Flow cytometry was carried out on a MACSQuant ${ }^{\circledR}$ Analyzer (Miltenyi Biotec, Bergisch Gladbach, Germany) and acquired data were analyzed using MACSQuantify ${ }^{\circledR}$ Software (Miltenyi Biotec) or FlowJo 10.1 Software (TreeStar Inc., Ashland, OR USA). Fluorescently labeled mAbs directed against human CD3 (clone BW264/56), CD4 (clone REA623), CD8 (clone REA734), CD69 (clone FN50), granzyme A (GzmA, clone REA162) and granzyme B (GzmB, clone REA226) as well as respective REA isotype controls (clone REA293) were purchased from Miltenyi Biotec. mAbs against human CD107a (clone H4A3) and IgG1 (isotype control, clone MOPC-21) were obtained from BD Biosciences Pharmingen. For the detection of E-tagged CAR constructs on genetically modified $\mathrm{T}$ cells, the $\alpha \mathrm{E}$-tag $\mathrm{mAb}$ (clone 7B6) and secondary goat anti-mouse IgG F(ab')2-PE $\mathrm{Ab}$ (Beckmann Coulter, Krefeld, Germany) were used [23].

After staining of extracellular markers and live vs. dead cell discrimination applying a Zombie Red ${ }^{\mathrm{TM}}$ Fixable Viability Kit (BioLegend, London, UK), T cells were processed using an Inside Stain Kit (Miltenyi Biotec) according to the manufacturer's protocol and subsequently labeled for intracellular markers.

\section{Cytotoxicity assays}

The elimination of CAR T cells by $\alpha$ E-tag CAR T cells was assessed using a previously established flow cytometrybased assay [33, 34]. To distinguish effector from target cells, the latter were labeled with $10 \mu \mathrm{M}$ cell proliferation dye eFluor ${ }^{\mathrm{TM}} 450$ (eBioscience, ThermoFisher Scientific) according to the manufacturer's instructions. The next day, effector cells ( $\alpha$ E-tag CAR T cells) were incubated with eFluor $^{\mathrm{TM}} 450$-stained CAR $28 / \zeta, \Delta$ CAR $28 / \zeta$ or CAR Stop $\mathrm{T}$ cells at indicated effector to target cell $(E: T)$ ratios. After indicated time points, cocultures were carefully resuspended and an aliquot of $25 \mu \mathrm{l}$ diluted $1: 4$ with $1 \mu \mathrm{g} / \mathrm{ml}$ propidium iodide (Sigma-Aldrich, Munich, Germany) was measured at a MACSQuant ${ }^{\circledR}$ Analyzer. After exclusion of doublets and dead cells, cells $/ \mathrm{ml}$ were assessed for both effector and target $\mathrm{T}$ cells separately. Finally, cells of one triplet were pooled, 
stained for intracellular expression of GzmA and GzmB, and analyzed by flow cytometry.

The antitumor activity of $\alpha$ E-tag CAR T cells was determined in standard chromium-51 release assays as previously reported [25].

\section{T-cell activation and degranulation assay}

A total of $5 \times 10^{5}$ eFluor ${ }^{\mathrm{TM}} 450$-labeled CAR $28 / \zeta, \Delta$ CAR $28 / \zeta$ or CAR Stop T cells was cultured together with equal numbers of $\alpha$ E-tag CAR T cells. Additionally, $5 \mu \mathrm{l}$ of $\alpha \mathrm{CD} 107 \mathrm{a}$ $\mathrm{mAb}$ or IgG1 isotype control were pipetted to each well. After $1 \mathrm{~h}$ of incubation at $37^{\circ} \mathrm{C}, 1 \mu \mathrm{l}$ of $2 \mathrm{mM}$ monensin (Sigma-Aldrich) was added. After $20 \mathrm{~h}$, cells were harvested, stained with $\alpha \mathrm{CD} 69$ and $\alpha \mathrm{CD} 3 \mathrm{mAb}$ and measured using a MACSQuant ${ }^{\circledR}$ Analyzer. Living cells were distinguished from dead cells by being propidium iodide negative.

\section{Cytokine release assay}

For analysis of TNF, IFN- $\gamma$, GM-CSF and IL-2 concentrations in cell-free culture supernatants (stored at $-80{ }^{\circ} \mathrm{C}$ ) enzyme-linked immunosorbent assay (ELISA) was conducted using OptEIA ${ }^{\mathrm{TM}}$ Human ELISA Kits (BD Biosciences Pharmingen) according to the manufacturer's protocol.

\section{Optical imaging of tumor xenograft mice}

Five-week-old male NMRI-Foxn $1^{\mathrm{nu}} / \mathrm{Foxn} 1^{\mathrm{nu}}$ mice were s.c. injected into their right flank with $5 \times 10^{5}$ firefly luciferase (Luc)-expressing PC3-PSCA cells ( $n=5$ per group). Control animals received tumor cells only or tumor cells mixed with either $5 \times 10^{5}$ CAR $28 / \zeta$ T cells or $15 \times 10^{5} \alpha$ E-tag CAR T cells. For induction of anti-tumor activity, $10 \mu \mathrm{g}$ of E5B9- or E7B6-tagged $\alpha$ PSCA TM was administered in addition to tumor cells and CAR-engrafted T cells. To impair the anti-tumor response, one group of mice was transplanted with PC3-PSCA-Luc cells, $10 \mu \mathrm{g} \alpha \mathrm{PSCA}-\mathrm{E} 5 \mathrm{~B} 9 \mathrm{TM}$, $5 \times 10^{5}$ E-tagged CAR target T cells, and $15 \times 10^{5} \alpha \mathrm{E}$-tag CAR effector T cells. Animals were anesthetized $6 \mathrm{~h}, 1$ day and 2 days post-cell mixture injection and bioluminescence imaging was conducted as described elsewhere [26, 32]. Optical images were created with Bruker Multispectral software (Bruker, Germany).

\section{Statistical analysis}

Statistical significance was evaluated with GraphPad Prism 7 software (GraphPad Software Inc., La Jolla, CA, USA).
Statistical tests were used as indicated in figure legends. $p$ values of less than 0.05 were considered significant.

\section{Results}

\section{Generation of an aCAR CAR construct for the depletion of CAR-expressing T cells}

For targeting of CAR-modified T cells, we compared and tested different short peptide tags that can be incorporated into the extracellular part of both our conventional CARs as well as our UniCARs (data not shown). Thereby, we identified a short epitope derived from the nuclear protein La/SS-B (E-tag) as the most suitable tag for our approach. It could be integrated without impairing the in vitro or in vivo functionality of CAR T cells as previously published [23, 24, 26, 27, 32, 35-38]. The 18-aalong sequence E7B6 (EKEALKKIIEDQQESLNKW) is specifically bound by the $\alpha \mathrm{La} 7 \mathrm{~B} 6 \mathrm{mAb}$ [39]. Consequently, we cloned a CAR with a 7B6-derived scFv as the antigen-binding moiety and termed the resulting $\alpha C A R$ construct $\alpha E$-tag CAR (Fig. 1a). The $\alpha$ E-tag CAR construct recognizes the peptide tag E7B6 located in the hinge region of CARs. Upon antigen recognition, $\alpha \mathrm{E}-\mathrm{tag}$ CAR effector cells are cross-linked to target cells, which should result in the elimination of the latter. For signal transduction, the newly generated CAR contains the activating cytoplasmic domains of $\mathrm{CD} 3$ and $\mathrm{CD} 28$. Isolated $\mathrm{CD}^{+} \mathrm{T}$ cells from healthy donors could be successfully modified to express the novel CAR with $\mathrm{CD} 4^{+}$and $\mathrm{CD} 8^{+}$ subpopulations yielding comparable transduction rates (supplementary Fig. 1a).

\section{Specific elimination of CAR T cells using aE-tag CAR-engineered $T$ cells}

To test functionality of the novel $\alpha$ E-tag CAR construct, flow cytometry-based cytotoxicity assays were performed. As target cells, T lymphocytes were used that express a UniCAR containing the extracellular E-tag and an intracel-

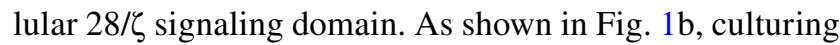
these cells together with mock-transduced control cells did not influence viability. In contrast, adding $\alpha$ E-tag CAR effector T cells resulted in significant elimination of target $\mathrm{T}$ cells. Expectedly, T-cell killing was dependent on the $E: T$ ratio. To verify that the observed cytotoxic effect is due to specific recognition and binding of the incorporated peptide epitope, experiments with E-tag-deleted CAR T

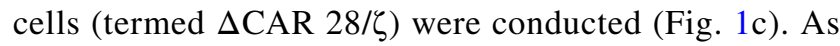
anticipated, $\triangle$ CAR $28 / \zeta$-engineered lymphocytes were not targeted by $\alpha E$-tag CAR effector T cells. In addition, we 

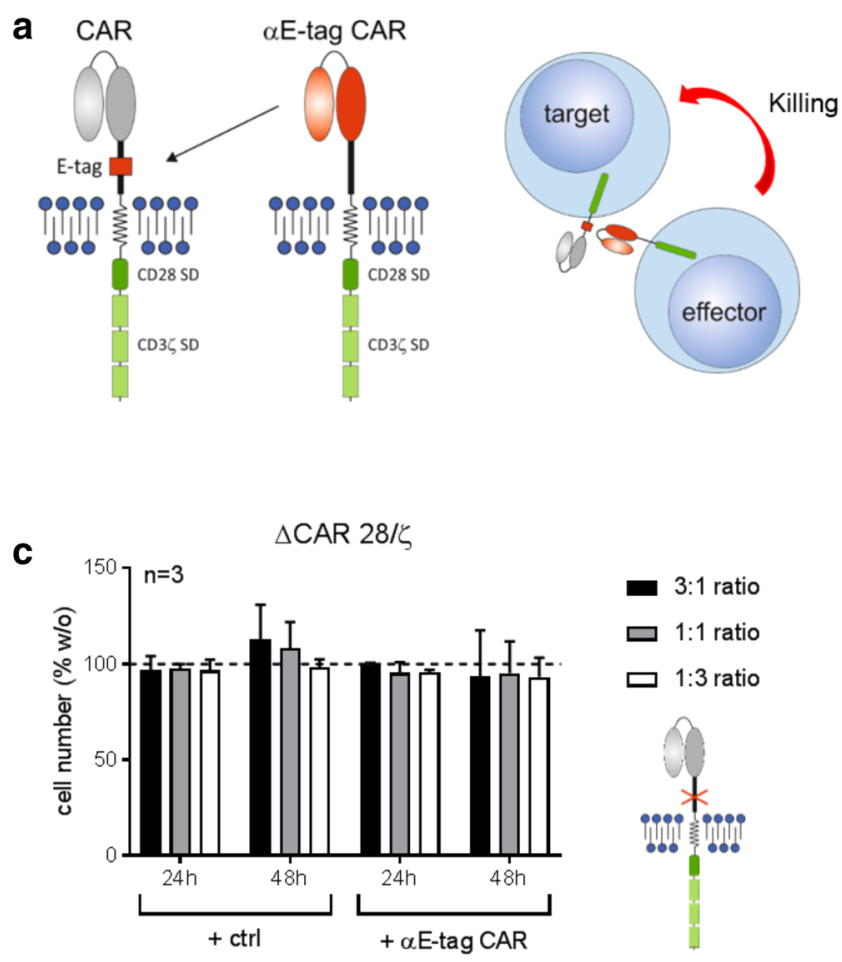

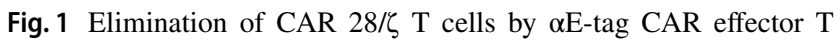
cells. a Schematic representation of an $\alpha E-t a g$ CAR and its mode of action. b-d UniCAR-modified T cells either containing (CAR 28/丂) or lacking $(\triangle \mathrm{CAR} 28 / \zeta)$ the extracellular E-tag were incubated with $\alpha$ E-tag CAR effector or mock-transduced (ctrl) $\mathrm{T}$ cells at indicated $E: T$ ratios. Diagrams show cell number of $\mathbf{b}$ eFluor ${ }^{\mathrm{TM}} 450^{+} \mathrm{CAR}$

monitored the number of living effector T cells after $24 \mathrm{~h}$ and $48 \mathrm{~h}$ of coculture. To our surprise, $\mathrm{T}$ cells redirected against the E-tag were significantly reduced in cell number whilst viability was maintained in the presence of $\triangle \mathrm{CAR}$

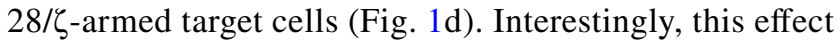
inversely correlated with the chosen $E: T$ ratio. To confirm these results, we, furthermore, tested whether E-tagged CAR constructs with different antigen specificity can be targeted as well. In accordance with the data obtained for UniCAR-armed target cells, T cells expressing an $\alpha \mathrm{CD} 19$ or an $\alpha$ PSCA conventional CAR (containing the extracellular E-tag) were specifically eliminated upon coculture with $\alpha$ E-tag CAR effector T cells already after $24 \mathrm{~h}$ (supplementary Fig. 1b). Again, survival of $\alpha$ CAR-redirected effector cells was affected by coculture with target cells in an $E: T$-dependent manner.

In a next step, we aimed to clarify whether the diminished effector T-cell number was merely a result of T-cell activation/exhaustion or reflects apoptosis actively induced by cross-linked target cells. For that purpose, expression of activation-induced CD69 as well as CD107a was evaluated (Fig. 2). The latter not only represents a marker for b

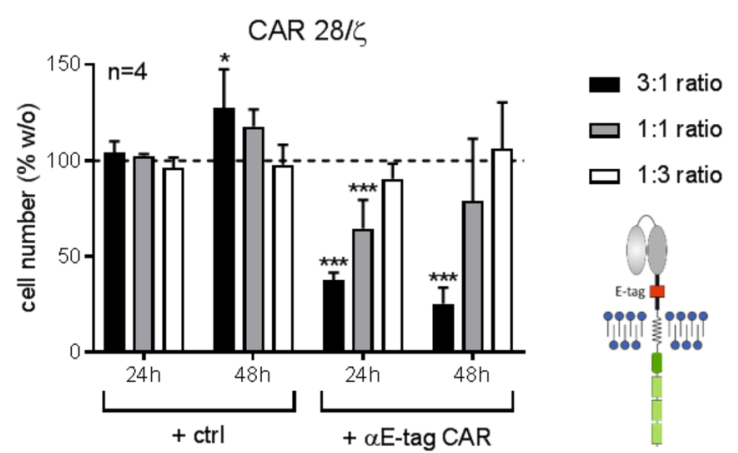

d

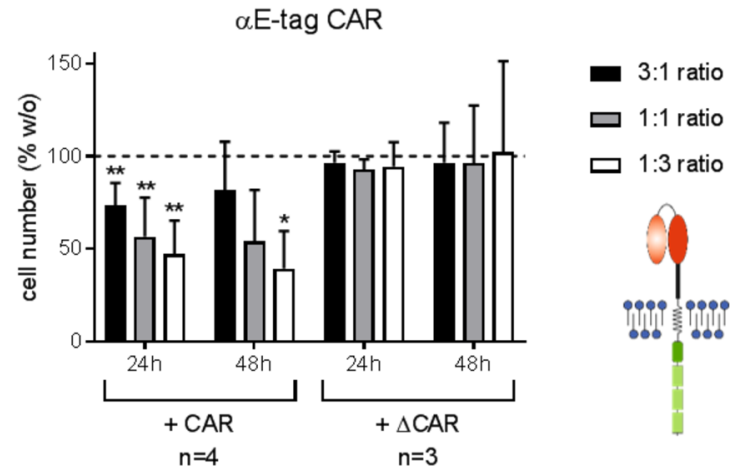

$28 / \zeta \mathrm{T}$ cells, $\mathbf{c}$ eFluor ${ }^{\mathrm{TM}} 450^{+} \Delta \mathrm{CAR} 28 / \zeta \mathrm{T}$ cells, or $\mathbf{d}$ unstained $\alpha$ E-tag CAR effector cells. Absolute cell numbers alone were set to $100 \%$ and relative cell number in the presence of effector/target cells was calculated. Statistical significance was determined by oneway ANOVA with Bonferroni multiple comparison test $\left({ }^{*} p<0.05\right.$, $* * p<0.01, * * * p<0.001$ with respect to $\mathrm{T}$ cells cultured alone)

degranulation but was also recently described as a marker protein for fratricide of $\mathrm{T}$ cells [40]. In accordance with cytotoxicity data, $\alpha \mathrm{E}$-tag CAR effector $\mathrm{T}$ cells selectively upregulated both CD69 and CD107a in the presence of

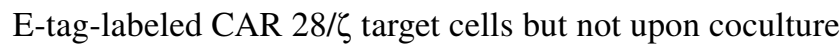
with $\triangle$ CAR $28 / \zeta$-equipped lymphocytes (Fig. 2b). Regarding CD69 and CD107a on the target cell side, T cells lacking the peptide epitope did not increase expression of neither of the analyzed surface molecules (Fig. 2c). However, target cells harboring the E-tag were stimulated and degranulated upon coincubation with $\alpha \mathrm{E}-\operatorname{tag} \mathrm{CAR}$ effector $\mathrm{T}$ cells. These results indicate that cross-linkage of effector and target $\mathrm{T}$ cells triggers activation of both cell types and subsequent reciprocal T-cell elimination.

\section{Reciprocal T-cell killing is dependent on the intracellular signaling domain}

The data obtained so far clearly demonstrate functionality of the novel $\alpha \mathrm{E}$-tag CAR construct. However, binding

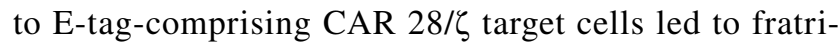
cide especially at low $E: T$ ratios. This could either be due 
a

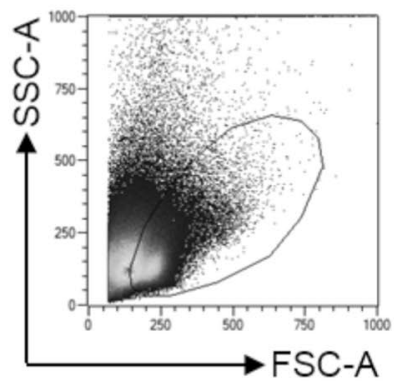

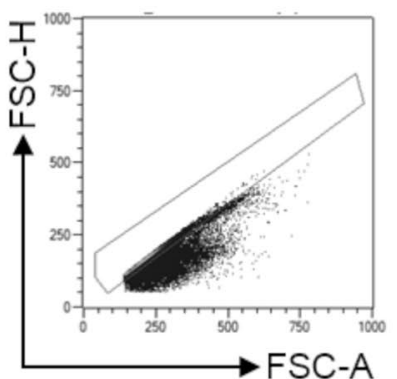
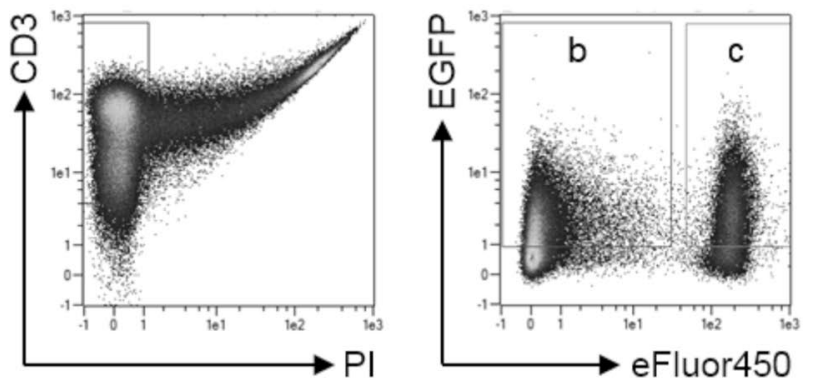

b $\alpha E$-tag CAR
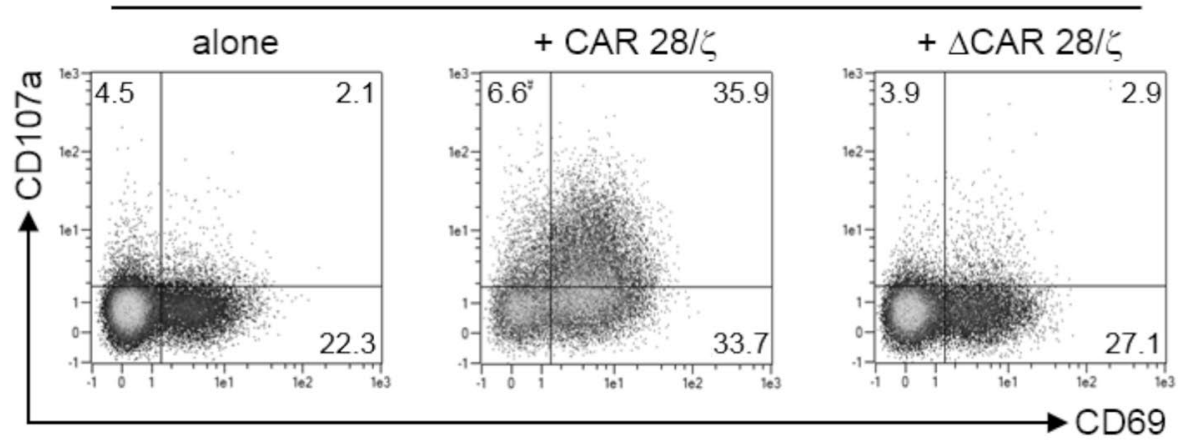

C

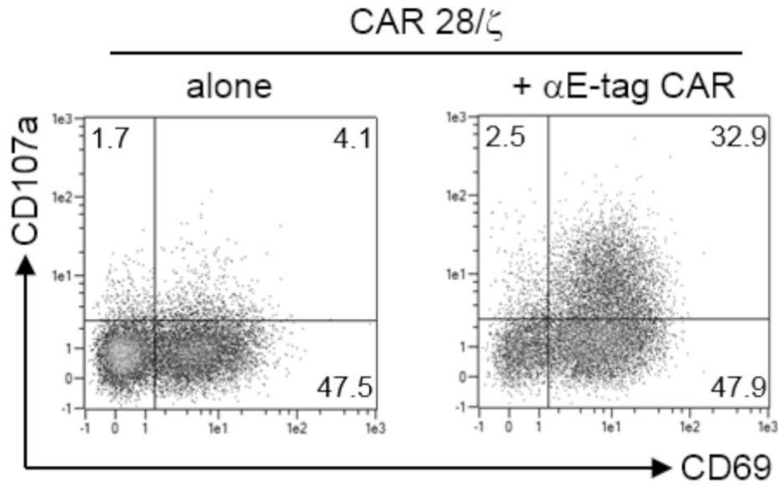

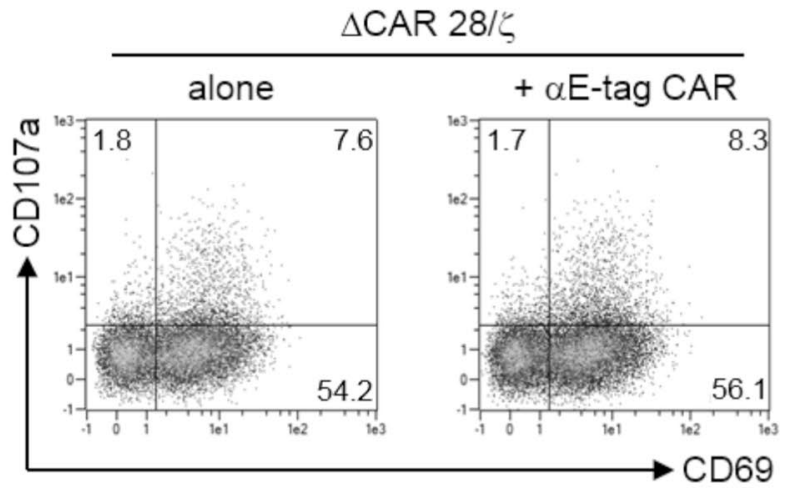

phocyte scatter gate followed by exclusion of doublets, then gating on living $\mathrm{T}$ cells and finally on $\mathrm{EGFP}^{+}$eFluor $450^{-}$effector cells and EGFP $^{+}$eFluor $450^{+}$target cells. $\mathbf{b}, \mathbf{c}$ Density plots show percentage of $\mathrm{CD} 9^{+}$and/or CD107 $\mathrm{a}^{+} \mathbf{b}$ effector and $\mathbf{c}$ target cells for one out of three representative donors

with this observation, only redirected effector $\mathrm{T}$ cells but not E-tag-labeled target cells were activated and degranulated upon cross-linkage (Fig. 3c). Hence, these data clearly demonstrate that reciprocal elimination of CARarmed $\mathrm{T}$ cells occurs in dependence on an intracellular signaling domain.

To investigate which cell type prevails in coculture, longterm cytotoxicity assays were conducted (supplementary Fig. $2 \mathrm{a}$ and $2 \mathrm{~b}$ ). The outcome was both dependent on the targeted CAR construct as well as the $E$ : $T$ ratio. Cells modified to express an E-tag-containing $\alpha \mathrm{CD} 19$ or $\alpha$ PSCA conventional CAR were efficiently eradicated long term at $E: T$ 


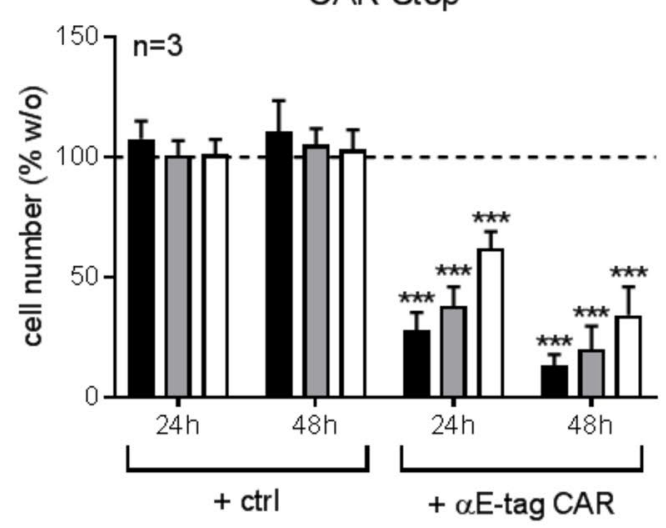

C

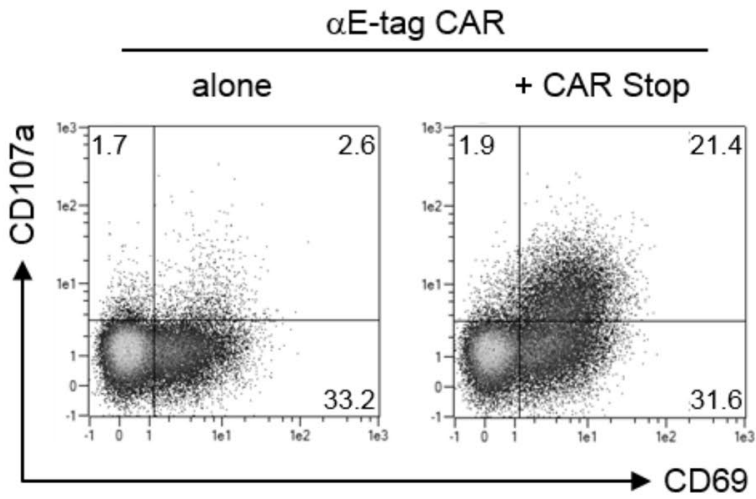

Fig. 3 Elimination of CAR Stop T cells by $\alpha$ E-tag CAR T cells. T cells transduced with an E-tagged CAR construct lacking an intracellular signaling domain (CAR Stop) were incubated with $\alpha E$-tag CAR effector or mock-transduced (ctrl) $\mathrm{T}$ cells at indicated ratios. Cell number of a eFluor ${ }^{\mathrm{TM}} 450$-stained target cells or $\mathbf{b}$ unstained effector cells was assessed after $24 \mathrm{~h}$ and $48 \mathrm{~h}$. Number of T cells cultured

ratios of 3:1 and 1:1. Compared to this, UniCAR target cells were completely eliminated only at the highest $E: T$ ratio tested. Thus, the prerequisite for an efficient T-cell-based $\alpha \mathrm{CAR}$ therapy is that the $E: T$ ratio is in favor of the $\alpha \mathrm{E}$-tag effector T cells.

\section{Effector cells upregulate CAR expression upon target T-cell killing}

In previous studies, we observed that the expression of cotranslated EGFP marker protein directly correlates with surface expression of CAR constructs [e.g., 23, 24]. Usually, we verify CAR T-cell expression via an $\alpha \mathrm{E}$-tag mAb (supplementary Fig. 3). As $\alpha$ E-tag CARs lack any extracellular tags, we monitored EGFP signal of T cells as a surrogate for CAR expression level changes (Fig. 4a). Upon activation, effector cells strongly upregulated the expression of their $\alpha$ E-tag CAR as shown for cocultivation with CAR Stopmodified target cells at all tested $E: T$ ratios as well as for a b

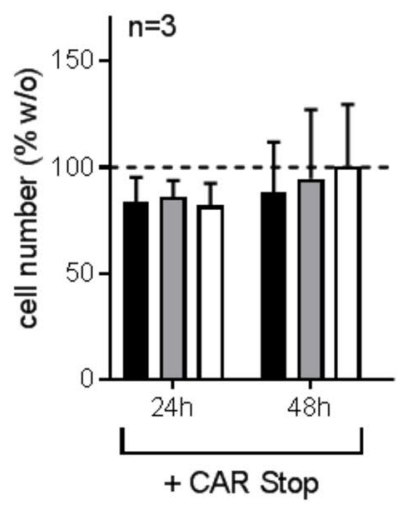

3:1 ratio

$3: 1$ ratio

$1: 1$ ratio

$1: 3$ ratio

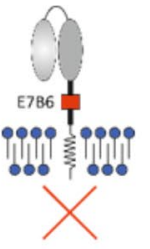

$\square$ 1:1 ratio

$\square$ 1:3 ratio

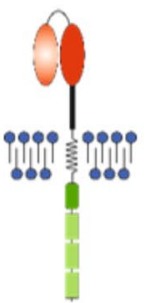

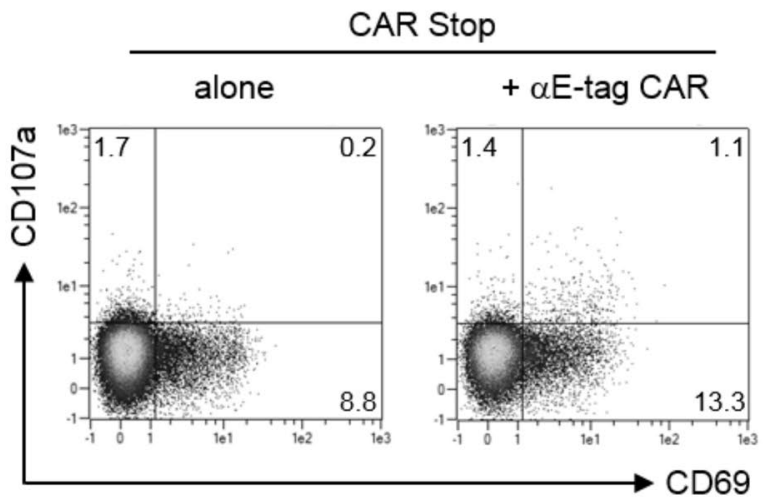

alone was equalized to $100 \%$ and percentage of cells in the presence of effector/target cells calculated $(* * * p<0.001$ with respect to T cells cultured alone; one-way ANOVA with Bonferroni multiple comparison test). c Percentage of $\mathrm{CD}^{+} 9^{+}$and/or CD107a ${ }^{+} \mathrm{EGFP}^{+} \alpha \mathrm{E}-$ tag CAR effector or CAR Stop target $\mathrm{T}$ cells after $24 \mathrm{~h}$ of coculture from one out of three representative T-cell donors

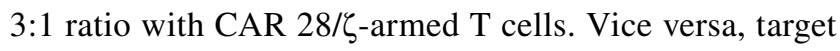
cells that receive an activating signal via their intracellular $28 / \zeta$ domain upon cross-linkage to effector cells also increased CAR expression (Fig. 4a, lower panel, 1:1 and $1: 3$ ratio). When analyzing the remaining E-tag-labeled $\mathrm{T}$ cells it becomes obvious that they showed reduced EGFP levels compared to conditions in which they were cultured in the absence of effector cells [e.g., CAR Stop: 9.6 vs. 1.0, 2.0 and 2.5 median fluorescence intensity (MFI) of EGFP at 3:1, $1: 1$ and $1: 3$ ratio, respectively]. This might be caused by the downregulation of the E-tag-containing CAR, yet, a more likely explanation is the preferential killing of T cells displaying a high CAR expression than of cells expressing only low levels of E-tag-comprising CARs. To substantiate this hypothesis, we analyzed elimination kinetics of target cells that were presorted into CAR low- and CAR high-expressing subpopulations based on the strength of their EGFP signal (supplementary Fig. 4). Compared to their EGFP ${ }^{\text {low }}$ counterpart, target $\mathrm{T}$ cells exhibiting high CAR densities were 


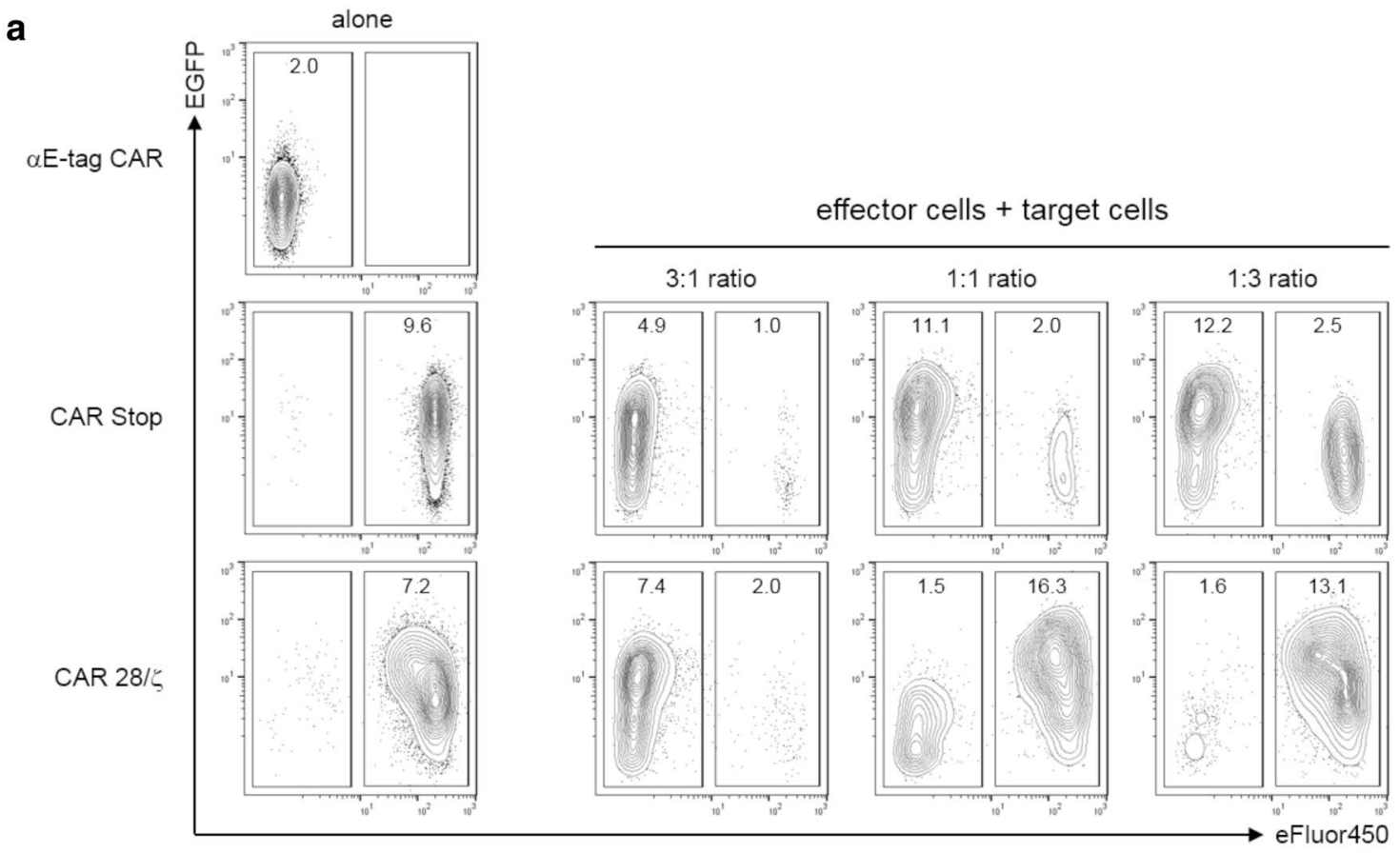

b

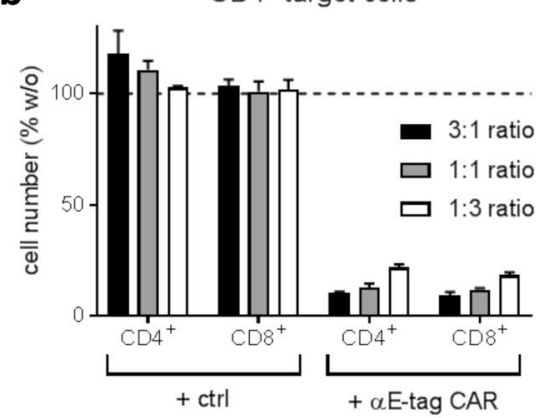

$\mathrm{CD} 8^{+}$target cells

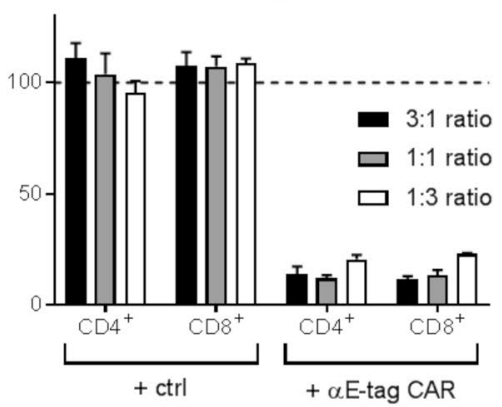

aE-tag CAR effector cells

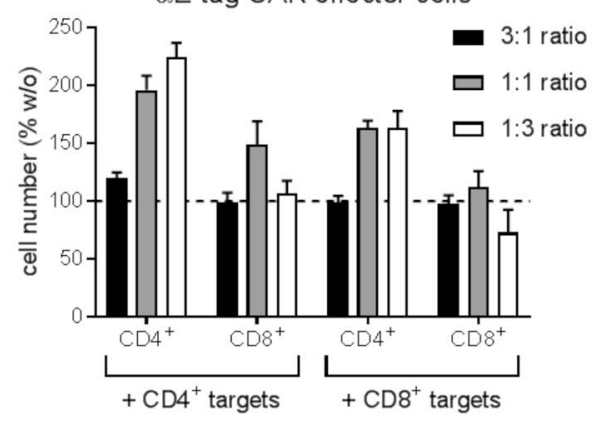

Fig. 4 Analysis of CAR expression levels and killing efficiencies of T-cell subpopulations. a Numbers in contour plots represent MFI of EGFP for both $\alpha$ E-tag CAR effector cells (eFluor ${ }^{\mathrm{TM}} 450^{-}$) and CAR Stop or CAR $28 / \zeta$ target cells (eFluor ${ }^{\mathrm{TM}} 450^{+}$) after 2 days of coculture. Results are reported for one representative donor out of three. $\mathbf{b}$ $\mathrm{CD}^{+}{ }^{+}$and $\mathrm{CD}^{+}$CAR Stop T cells were incubated at indicated $E: T$

indeed more efficiently killed. In accordance, expansion of $\alpha \mathrm{E}$-tag CAR effector $\mathrm{T}$ cells that were incubated with EGFP $^{\text {high }}$ target $T$ cells was more pronounced than in cocultures with sorted EGFP ${ }^{\text {low }}$ cells. Together, these data support our assumption that high E-tagged CAR expression results in preferential target cell killing.

\section{$\mathrm{CD}^{+}$and $\mathrm{CD}^{+}$target $\mathrm{T}$ cells are equally well depleted by $\mathrm{CD4}^{+}$and $\mathrm{CD}^{+}$effector T cells}

As we established a functional $\alpha$ CAR CAR for efficient depletion of genetically modified $\mathrm{T}$ cells, we wanted to use this construct as a tool for investigating $\mathrm{CD} 4^{+}$and $\mathrm{CD} 8^{+}$ ratios with $\alpha$ E-tag CAR effector or CAR Stop (ctrl) T cells. After $48 \mathrm{~h}, \mathrm{CD}^{+}{ }^{+}$and $\mathrm{CD} 8^{+}$target and effector cells were quantified. Absolute numbers of $\mathrm{T}$ cells cultured alone were set to $100 \%$ and corresponding relative cell number in the presence of effector/target cells was calculated. Error bars represent SD of triplicate wells. Results for one representative donor are shown

T-cell killing capabilities in more detail. For that purpose, we isolated and transduced both subpopulations separately with either an E7B6-tagged CAR Stop or an $\alpha$ E-tag CAR. In subsequent flow cytometry-based cytotoxicity assays over $48 \mathrm{~h}$, both $\mathrm{CD}^{+}$and $\mathrm{CD} 8^{+}$effector cells performed equally well in killing of E-tag-containing CAR target $\mathrm{T}$ cells (Fig. 4b). However, the CD4 ${ }^{+}$T-cell subset demonstrated a stronger proliferative capacity compared to $\mathrm{CD} 8^{+}$ $\mathrm{T}$ cells, most likely due to the fact that the latter produce less growth-promoting IL-2 than T-helper cells. Again, monitoring the EGFP signal indicates that effector cells vigorously enhanced the expression of their $\alpha E$-tag CAR upon activation (supplementary Fig. 5a) and preferentially eliminated 
target cells with the high expression of the E-tag containing CAR (supplementary Fig. 5b). The cytotoxicity data further reveal that $\mathrm{CD}^{+}{ }^{+}$and $\mathrm{CD} 8^{+}$cells can be targeted efficiently with no apparent differences between the two T-cell populations (Fig. 4b).

To shed some light on the mode of action, intracellular staining for granzymes were conducted (supplementary Fig. 6a). As $\mathrm{CD} 8^{+} \mathrm{T}$ cells were already highly positive for GzmA in a resting state, upon cocultivation with target cells only GzmB was strongly upregulated. In contrast, CD4 ${ }^{+}$ T-cell activation induced expression of both GzmA and GzmB. Interestingly, we could detect elevated granzyme levels in target cells (supplementary Fig. 6b). As they were not expressing CD107a (see also Fig. 3c), we reason that GzmA and GzmB are not produced by target cells themselves but originated from effector cells and were transported via the cytolytic immune synapse. Further evidence to support this notion was obtained by staining target $\mathrm{T}$ cells that were cocultured with mock-transduced $\mathrm{T}$ cells instead of cytolytic effector cells. As shown in supplementary Fig. 6c, enhanced GzmA/GzmB was only detectable in E-tagged CAR T cells that were targeted by $\alpha E$-tag CAR effector T cells, whereas granzyme levels of target $\mathrm{T}$ cells cocultured with mock control resembled baseline expression.

\section{Killing of CAR T cells results in the abrogation of their effector functions in vitro and in vivo}

Having successfully shown that $\alpha \mathrm{CAR}$-engineered T cells attack E-tagged CAR T cells, we next wanted to clarify how this influences effector functions of the targeted lymphocytes. As readout, secretion of proinflammatory cytokines in vitro as well as tumor cell killing in vivo was chosen. As already stated above, one kind of E-tagged CARs are our switchable and flexible modular UniCARs [24, 26, 27, 32, 35-38]. Utilizing the La/SS-B-derived peptide epitope E5B9 as linker, the platform technology enables a precisely controlled activation of otherwise inert 5B9 UniCAR-armed T cells by infusion of small E5B9-tagged TMs (Fig. 5a, left panel). For proof-of-concept, we used these UniCAR cells as targets for $\alpha$ CAR-equipped cells and stimulated them against the tumor-associated antigen PSCA via an $\alpha$ PSCA-E5B9 TM. Activation resulted in the substantial release of proinflammatory TNF, GM-CSF and IFN- $\gamma$ as well as mitogenic IL-2 (Fig. 5b, striped bar). Addition of $\alpha$ E-tag CAR T cells resulted in a dose-dependent reduction of secreted cytokines. Interestingly, retargeting of $\alpha \mathrm{CAR} T$ cells against the E-tag did not trigger profound cytokine production (Fig. 5b and supplementary Fig. 7) which, in light of a putative clinical translation, is beneficial since it can be reasoned that T-cell-mediated CAR T-cell killing does not exacerbate cytokine release syndrome. As depicted in Fig. 5c, E-tagged UniCAR $28 / \zeta \mathrm{T}$ cells were not only eliminated in vitro but also in vivo. NMRI ${ }^{\text {nu/nu }}$ mice were transplanted with Lucexpressing PC3-PSCA cells and survival of tumor cells was monitored by means of bioluminescence imaging. Two days after the injection of $\mathrm{Luc}^{+}$PC3-PSCA cells, UniCAR 28/ל T cells and a cross-linking $\alpha$ PSCA-E5B9 TM, Luc activity was almost completely cleared. By contrast, anti-tumor activity was markedly impaired upon co-injection of $\alpha \mathrm{E}$-tag CAR $\mathrm{T}$ cells (Fig. 5c, right panel) verifying that $\alpha \mathrm{CAR}$-modified $\mathrm{T}$ cells are functional in experimental mice post-transfer and efficiently kill E-tagged target $\mathrm{T}$ cells in vivo.

\section{aE-tag CAR-engineered T cells can be repurposed for antitumor treatment in vitro and in vivo}

The complete eradication of a therapeutic CAR T-cell population inevitably entails termination of antitumor activity. In contrast to other currently available safety strategies, the $\alpha$ CAR CAR methodology provides the unique possibility to re-initiate tumor treatment as the $\alpha E$-tag CAR T cells can be repurposed as tumor-fighting CAR T cells. As schematically summarized in Fig. 5a, they may even replace the original therapeutic cell product and function as an alternative UniCAR variant which we termed '7B6 UniCAR' T cells. Like the original UniCARs which are directed against the peptide epitope E5B9, 7B6 UniCARs can be redirected by administering E-tag-comprising TMs (Fig. 5a, right panel). To support this idea, we generated two novel TMs consisting of either a murine or a humanized $\mathrm{scFv}$ against PSCA fused to the E-tag. Indeed, as demonstrated in Fig. 6a, these TMs efficiently mediated cross-linkage of $\alpha \mathrm{E}$-tag CAR T cells and PSCA-expressing PC 3 cells, resulting in significant tumor cell lysis in vitro. The TM-dependent anti-tumor response of $\alpha \mathrm{E}$-tag CAR-modified T cells could furthermore be substantiated in vivo (Fig. 6b). To that end, athymic nude mice were injected with Luc-expressing $\mathrm{PSCA}^{+}$tumor cells either alone or together with $\alpha$ E-tag CAR T cells with or without the humanized PSCA-binding E-tagged TM. After 2 days, Luc activity was no longer detectable in the treatment group (Fig. 6b, right panel) whilst tumor cells were still visible in both control groups (Fig. 6b, left and middle panel). Taken together, $\alpha$ E-tag CAR T cells can not only trigger elimination of autologous CAR T cells but can function as an alternative UniCAR variant if required.

\section{Discussion}

Although gene-modified CAR T cells have demonstrated unparalleled antitumor responses in hematological malignancies [2-6], adoptive therapy is often associated with severe, partly life-threatening side effects [4-11]. These side effects can be divided into short-time and long-time effects. For example, soon after the start of a CAR T-cell 


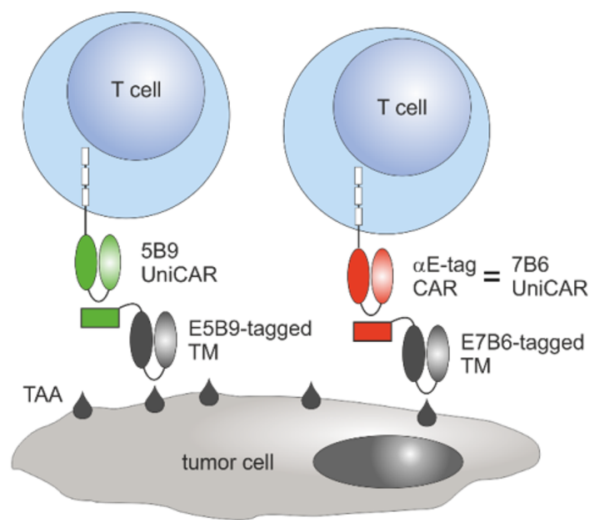

c

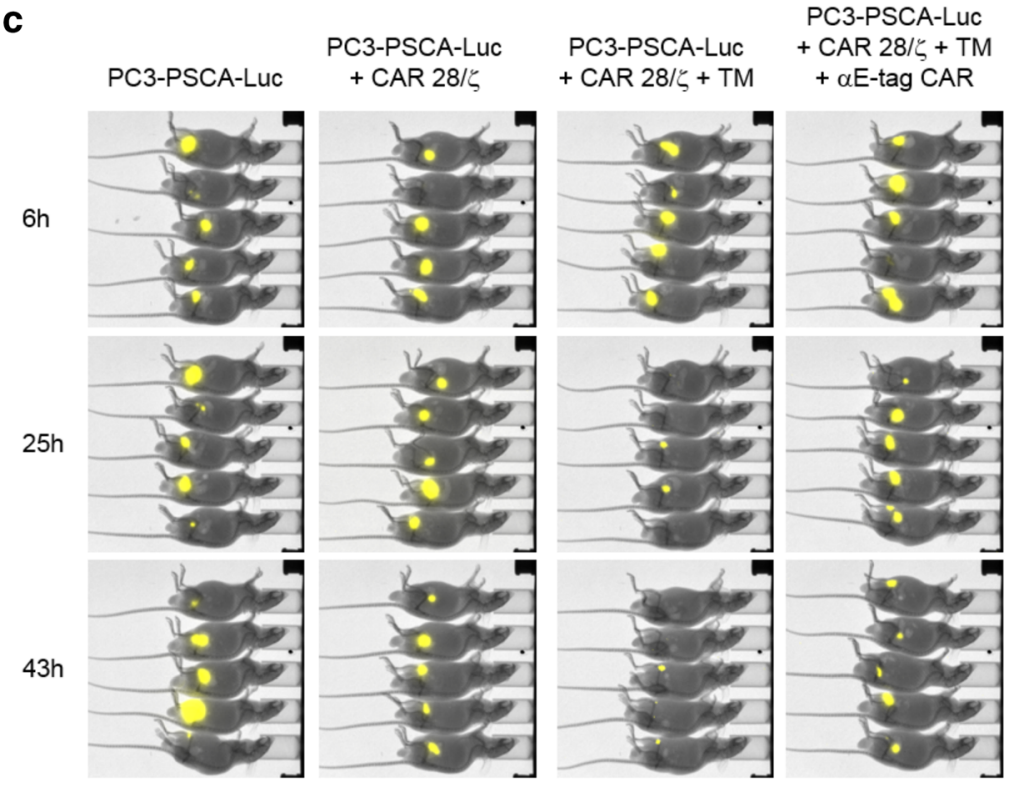

b

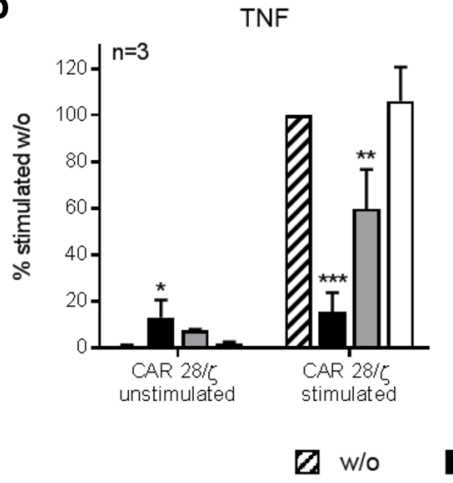

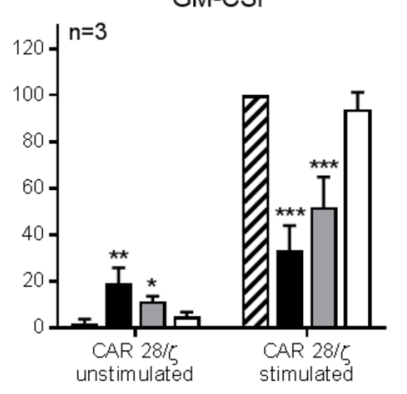
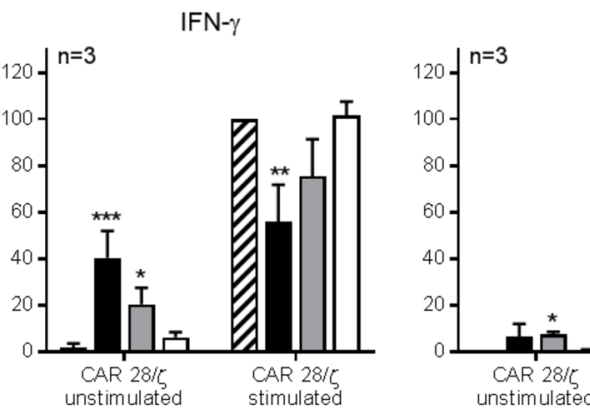

IL-2

$+\alpha \mathrm{E}$-tag CAR (1:1)

$+\alpha E-\operatorname{tag} \operatorname{CAR}(1: 3)$

Fig. 5 Impairment of effector functions of E-tagged CAR 28/ל T cells. a The physiologically inactive 5B9 UniCAR is switched on by a tumor-associated antigen (TAA)-binding TM comprising the peptide epitope E5B9 (left). Similarly, via E7B6-tagged TMs, $\alpha$ E-tag CAR T cells can be repurposed as alternative 7B6 UniCAR T cells (right). b CAR $28 / \zeta$ target T cells were left unstimulated or redirected to PC3-PSCA tumor cells using an $\alpha$ PSCA-E5B9 TM (stimulated). For target T-cell killing under both conditions, $\alpha$ E-tag CAR effector $\mathrm{T}$ cells were added at indicated $E: T$ ratios for $72 \mathrm{~h}$. Cytokine levels in the presence of $\alpha E$-tag CAR $\mathrm{T}$ cells were normalized to samples

therapy, the adoptively transferred $\mathrm{T}$ cells can rapidly expand potentially leading to a severe cytokine storm. In addition, the simultaneous disintegration of a huge number of tumor cells may cause a tumor lysis syndrome. After removal of the tumor cells still side effects may occur due to cross-reactivity of the anti-tumor domain of the CAR with healthy tissues as even seen with the CD19 CAR. For these reasons, safeguards to control toxicity are required. There are currently two major ideas followed to control such severe side effects: (i) elimination of CAR T cells and (ii) engineering of tunable CAR T cells based on molecular switches and/or combinatorial targeting according to the with stimulated CAR $28 / \zeta \mathrm{T}$ cells alone. $\left({ }^{*} p<0.05\right.$, ${ }^{*} p<0.01$, $* * * p<0.001$ with respect to CAR $28 / \zeta$ target $\mathrm{T}$ cells w/o effector $\mathrm{T}$ cells, one-way ANOVA with Bonferroni multiple comparison test). c Bioluminescence imaging of anesthetized mice was conducted at indicated time points post tumor cell injection. Control animals were transplanted with PC3-PSCA-Luc tumor cells alone or together with

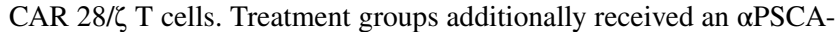
E5B9 TM in the presence or absence of autologous $\alpha$ E-tag CAR T cells $(E: T$ ratio $3: 1)$

rules of Boolean algebra [41, 42]. The activity of switchable CARs can be controlled, e.g., by soluble tumor-specific Ab-based components such as the TMs in the UniCAR system [24, 26, 27, 32, 35-38] or even chemically tuned via small molecules (ON-switch CARs) [43]. Bearing the high costs of CAR T-cell products in mind, approaches aiming to fine-tune CAR T cells should be favored in the first place. However, it would be advantageous to have an additional safeguard available if switchable CARs do not behave as predicted. Although unlikely for terminally differentiated cells and not observed until now, one should always keep in mind that genetic manipulation of cells 
a

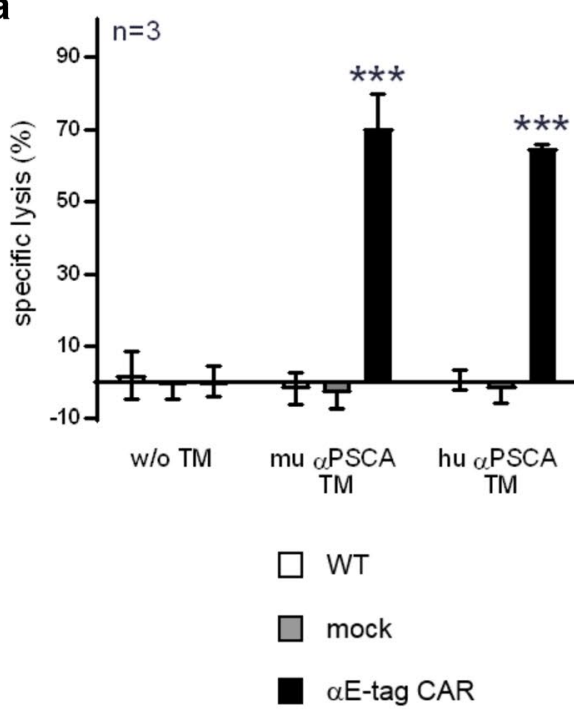

b

$6 h$

$25 h$

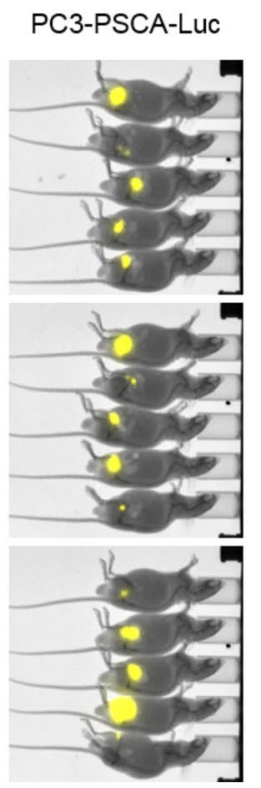

PC3-PSCA-LUC

$+\alpha$ E-tag CAR

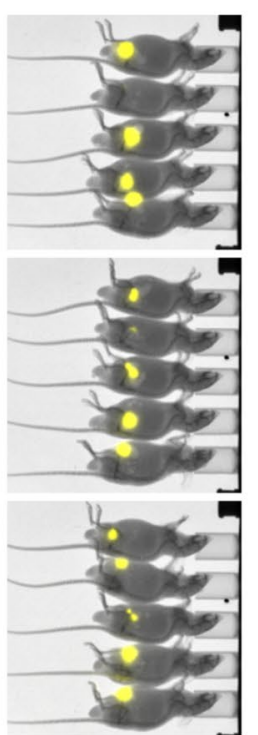

PC3-PSCA-LUC

$+\alpha E-\operatorname{tag} C A R+T M$

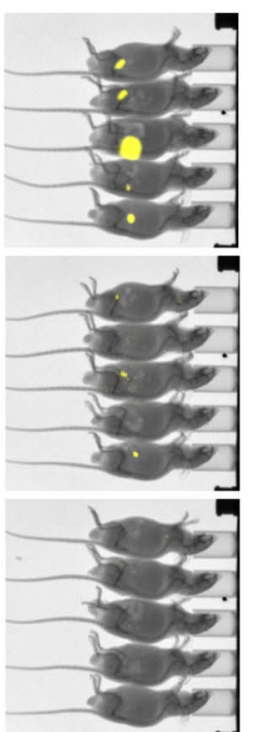

Fig. 6 Killing of tumor cells by $\alpha E$-tag CAR $\mathrm{T}$ cells redirected via E7B6-tagged TMs. a $\alpha$ E-tag CAR T cells were incubated with chromium-labeled PC3-PSCA tumor cells (E:T ratio of 5:1) either with or without a murine $(\mathrm{mu})$ or humanized $(\mathrm{hu}) \alpha$ PSCA-E7B6 TM. Nontransduced $\mathrm{T}$ cells (WT) or T cells expressing only EGFP (mock) served as negative control. After $48 \mathrm{~h}$, tumor cell lysis was assessed
(*** $p<0.001$, two-way ANOVA with Bonferroni multiple comparison test). $\mathbf{b}$ Bioluminescence images of mice that were s.c. injected with a mixture of Luc-expressing PC3-PSCA tumor cells and $\alpha \mathrm{E}$-tag CAR $\mathrm{T}$ cells with or without a hu $\alpha$ PSCA-E7B6 TM. Tumor-only control animals are the same as presented in Fig. $5 \mathrm{c}$, due to experiments being performed in parallel harbors the risk to generate leukemic CAR T cells either by accidentally transducing single leukemic cells during the manufacturing process or by insertional mutagenesis. In case such leukemic CAR T cells develop, elimination strategies for both conventional and switchable CAR T cells are highly required.

Here, we report an efficient chance to selectively deplete genetically engineered $\mathrm{T}$ cells by autologous $\alpha \mathrm{CAR}$ redirected $\mathrm{T}$ cells. For this purpose, we have integrated a specific peptide epitope (E7B6) into the CAR architecture that can be used as an inherent elimination tag. Based on a mAb recognizing this tag, an $\alpha \mathrm{E}$-tag CAR construct was designed and successfully generated. Using flow cytometry-based cytotoxicity assays we demonstrate that $\mathrm{T}$ cells equipped with this novel CAR selectively bind and eliminate CAR T cells with an incorporated E-tag whilst CAR T cells lacking this tag are not attacked.

Even though the $\mathrm{CD} 8^{+}$subpopulation has long been considered as the most potent T-cell subtype in terms of cytotoxicity, our killing data reveal that $\mathrm{CD} 4^{+}$effector $\mathrm{T}$ cells eliminate target cells equally efficient via granzymemediated apoptosis. One likely explanation is that our readout is performed after $24 \mathrm{~h}$ and $48 \mathrm{~h}$, whilst other studies perform short-term cytotoxicity assays over $4 \mathrm{~h}$ [e.g., 44]. In that regard, we have previously published that the onset of killing via $\mathrm{CD} 4^{+} \mathrm{T}$ cells is delayed, with no obvious effects seen $5 \mathrm{~h}$ or $6 \mathrm{~h}$ after stimulation. Yet, upon prolonging incubation to $20 \mathrm{~h}$, a substantial cytotoxic activity comparable to that of $\mathrm{CD} 8^{+} \mathrm{T}$ cells is detectable $[34,45]$.

Our data further indicate that target cells expressing high CAR levels are more prone to depletion by $\alpha E$-tag redirected effectors than cells with low CAR expression. This is in accordance with previously published studies reporting a positive correlation between the number of EGFR cellsurface molecules and cetuximab-triggered $\operatorname{ADCC}[18,46]$. However, in the aforementioned study and other currently investigated safety strategies, the suicide/elimination marker is separated from the CAR construct [13-18, 20]. Given that $\mathrm{T}$ cells with low safeguard molecule expression display a reduced susceptibility to apoptosis, CAR-engineered T cells lacking the suicide/elimination marker might emerge due to selective pressure. These cells ultimately escape control and perpetuate toxicity. By contrast, integrating the E-tag into the extracellular spacer region of the CAR should prevent CAR T-cell escape. An additional benefit of this approach is the small size of the peptide epitope of only 18 aa. Opposed to that, other proposed depletion markers are relatively large proteins that add a substantial payload to the expression vector potentially interfering with transcriptional efficiency. Most recently, a study reported the development of a so-called CubiCAR, combining three functions (detection, purification and depletion) in one CAR molecule by 
incorporating CD20 mimotopes and a CD34 epitope into the extracellular region of a CAR [47]. Although not investigated in the present manuscript, also the E-tag has utility beyond function as elimination marker. As previously shown, it enables detection, selective ex vivo expansion and purification of E-tagged CAR T cells prior to adoptive transfer [23]. In that regard, we reason that in vivo tracking of gene-modified cells using for example radio-labeled mAbs against the E-tag is feasible as well.

Despite the fact that all currently available elimination markers, in contrast to suicide genes, possess multifunctional characteristics [17-20, 47], several drawbacks are associated with the use of mAbs. First, the efficacy of CAR T-cell depletion via ADCC might be impaired in heavily preconditioned cancer patients due to their compromised immune system. Second, cetuximab and rituximab inevitably provoke on-target adverse effects upon recognition of healthy epidermal tissue and endogenous B cells, respectively. In this regard, using an epitope derived from the human nuclear La/SS-B protein provides a safe approach as the targeted antigen is not available on the surface of intact cells under physiological conditions [28, 48]. Third, to ensure therapeutic efficiency, a sufficiently high local $\mathrm{Ab}$ concentration is required which might not be achieved in all tissues due to limited penetration and retention of infused mAbs. In light of this and given that $T$ cells elicit highly potent cytotoxic effector mechanisms, $\alpha \mathrm{CAR}$-redirected $\mathrm{T}$ cells represent a promising approach to bypass the abovediscussed shortcomings of drug-based depletion strategies. In contrast to mAbs, $\mathrm{T}$ cells engraft and proliferate, hence, can be considered as self-amplifying "living drugs". Furthermore, they show better tissue penetration and might, therefore, be superior to mAbs in eliminating CAR T cells. Considering the high costs of CAR T-cell products, clinical application of $\alpha \mathrm{CAR} T$ cells as a safety switch may be particularly relevant (i) if other mechanisms/strategies fail to control serious treatment-related toxicities or (ii) if leukemic CAR T cells occur.

Nevertheless, once tumor-specific CAR T cells are completely wiped out, therapeutic antitumor activity cannot be retrieved. However, our proposed safety approach offers the unique feature of repurposing $\alpha \mathrm{CAR}$-engineered $\mathrm{T}$ cells as tumor-fighting UniCAR $\mathrm{T}$ cells by administration of an E-tag-comprising TM. Thereby, tumor treatment can be reinitiated on demand in case of relapse, which represents a substantial advantage over all currently available safeguard strategies.

In summary, we provide first experimental evidence for using $\alpha \mathrm{CAR}$-redirected $\mathrm{T}$ cells for selective elimination of gene-modified $\mathrm{T}$ cells in case of life-threatening CAR therapy-related side effects. For specific recognition of CARexpressing $\mathrm{T}$ cells, we integrated a small epitope tag (E-tag) into the CAR architecture without impairing functionality of the original construct. This E-tag then serves as a targetable moiety for specific and stringent CAR T-cell depletion via autologous $\alpha \mathrm{CAR}$-engrafted T cells. As the E-tag can be incorporated into all CARs irrespective of the targeted tumor antigen, it represents a promising universal tool to enhance safety of all kinds of cell-based immunotherapies.

Acknowledgements We thank Julia Lagler for excellent technical assistance.

Author contributions SK conceived and conducted all experiments, analyzed the data and wrote the manuscript. PZ-W, CA, and AF designed and cloned the $\alpha$ E-tag CAR $28 / \zeta$, the $\triangle$ CAR $28 / \zeta$ and the $\alpha$ PSCA-E7B6 TMs. RB performed the animal imaging experiments. $\mathrm{AK}, \mathrm{MC}, \mathrm{AE}, \mathrm{GE}$, and $\mathrm{MB}$ provided critical reagents, valuable input, and materials. MPB secured funding, contributed to data interpretation and wrote the manuscript.

Funding This work was supported by grants provided to Michael P. Bachmann by the German government [Federal Ministry of Education and Research (BMBF), Grant number 01EK1513 (TurbiCAR)].

\section{Compliance with ethical standards}

Conflict of interest Michael P. Bachmann is the inventor of the UniCAR platform and, together with Armin Ehninger and Gerhard Ehninger, is a shareholder of the company GEMoaB which holds licenses, patents, and has filed patent applications related to the UniCAR platform. Michael P. Bachmann and Armin Ehninger hold patents related to anti-La mAbs and the La epitopes used in this paper. Marc Cartellieri is an employee of Cellex PT. The remaining authors declare no conflict of interest.

Ethical approval and ethical standards The work regarding human $\mathrm{T}$ cells was approved by the local ethics committee of the university hospital of the Medical Faculty 'Carl Gustav Carus', Technische Universität Dresden (EK27022006). Animal experiments were performed at the Helmholtz-Zentrum Dresden-Rossendorf in accordance with the guidelines of German Regulations of Animal Welfare. The animal study has been approved by the local authorities (Landesdirektion Dresden, 24-9165.40-4, 24.9168.21e4/2004-1). This article does not contain studies with human participants by any of the authors.

Informed consent Buffy coats from healthy donors were supplied by the German Red Cross (Dresden, Germany) with written informed consent to use the blood for research purposes.

Animal source All mice used for this study were purchased from Janvier Labs, St. Berthevin, France.

Cell line authentication HEK293T (CRL-11268), PC3 (CRL-1435), 3 T3 (CRL-1658), and CHO (CCL-61) cells were obtained from the American Type Culture Collection. As they were recently bought, no further authentication was performed.

Open Access This article is distributed under the terms of the Creative Commons Attribution 4.0 International License (http://creativeco mmons.org/licenses/by/4.0/), which permits unrestricted use, distribution, and reproduction in any medium, provided you give appropriate credit to the original author(s) and the source, provide a link to the Creative Commons license, and indicate if changes were made. 


\section{References}

1. Cartellieri M, Bachmann M, Feldmann A, Bippes C, Stamova S, Wehner R, Temme A, Schmitz M (2010) Chimeric antigen receptor-engineered $\mathrm{T}$ cells for immunotherapy of cancer. J Biomed Biotechnol 2010:956304. https://doi.org/10.1155/2010/956304

2. Brentjens RJ, Rivière I, Park JH, Davila ML, Wang X, Stefanski J, Taylor C, Yeh R, Bartido S, Borquez-Ojeda O, Olszewska M, Bernal Y, Pegram H, Przybylowski M, Hollyman D, Usachenko Y, Pirraglia D, Hosey J, Santos E, Halton E, Maslak P, Scheinberg D, Jurcic J, Heaney M, Heller G, Frattini M, Sadelain M (2011) Safety and persistence of adoptively transferred autologous CD19-targeted T cells in patients with relapsed or chemotherapy refractory B-cell leukemias. Blood 118(18):4817-4828. https://doi.org/10.1182/blood-2011-04-348540

3. Kalos M, Levine BL, Porter DL, Katz S, Grupp SA, Bagg A, June CH (2011) T cells with chimeric antigen receptors have potent antitumor effects and can establish memory in patients with advanced leukemia. Sci Transl Med 3(95):95ra73. https:// doi.org/10.1126/scitranslmed.3002842

4. Kochenderfer JN, Dudley ME, Feldman SA, Wilson WH, Spaner DE, Maric I, Stetler-Stevenson M, Phan GQ, Hughes MS, Sherry RM, Yang JC, Kammula US, Devillier L, Carpenter R, Nathan DA, Morgan RA, Laurencot C, Rosenberg SA (2012) B-cell depletion and remissions of malignancy along with cytokine-associated toxicity in a clinical trial of antiCD19 chimeric-antigen-receptor-transduced T cells. Blood 119(12):2709-2720. https://doi.org/10.1182/blood-2011-10384388

5. Maude SL, Frey N, Shaw PA, Aplenc R, Barrett DM, Bunin NJ, Chew A, Gonzalez VE, Zheng Z, Lacey SF, Mahnke YD, Melenhorst JJ, Rheingold SR, Shen A, Teachey DT, Levine BL, June CH, Porter DL, Grupp SA (2014) Chimeric antigen receptor T cells for sustained remissions in leukemia. N Engl J Med 371(16):1507-1517. https://doi.org/10.1056/NEJMoa1407222

6. Lee DW, Kochenderfer JN, Stetler-Stevenson M, Cui YK, Delbrook C, Feldman SA, Fry TJ, Orentas R, Sabatino M, Shah NN, Steinberg SM, Stroncek D, Tschernia N, Yuan C, Zhang H, Zhang L, Rosenberg SA, Wayne AS, Mackall CL (2015) T cells expressing CD19 chimeric antigen receptors for acute lymphoblastic leukaemia in children and young adults: a phase 1 dose-escalation trial. Lancet 385(9967):517-528. https://doi.org/10.1016/S0140 $-6736(14) 61403-3$

7. Davila ML, Riviere I, Wang X, Bartido S, Park J, Curran K, Chung SS, Stefanski J, Borquez-Ojeda O, Olszewska M, Qu J, Wasielewska T, He Q, Fink M, Shinglot H, Youssif M, Satter M, Wang Y, Hosey J, Quintanilla H, Halton E, Bernal Y, Bouhassira DC, Arcila ME, Gonen M, Roboz GJ, Maslak P, Douer D, Frattini MG, Giralt S, Sadelain M, Brentjens R (2014) Efficacy and toxicity management of $19-28 \mathrm{z}$ CAR T cell therapy in B cell acute lymphoblastic leukemia. Sci Transl Med 6(224):224ra25. https:// doi.org/10.1126/scitranslmed.3008226

8. Lamers CH, Sleijfer S, Vulto AG, Kruit WH, Kliffen M, Debets R, Gratama JW, Stoter G, Oosterwijk E (2006) Treatment of metastatic renal cell carcinoma with autologous T-lymphocytes genetically retargeted against carbonic anhydrase IX: first clinical experience. J Clin Oncol 24(13):e20-e22. https://doi.org/10.1200/ JCO.2006.05.9964

9. Morgan RA, Yang JC, Kitano M, Dudley ME, Laurencot CM, Rosenberg SA (2010) Case report of a serious adverse event following the administration of $\mathrm{T}$ cells transduced with a chimeric antigen receptor recognizing ERBB2. Mol Ther 18(4):843-851. https://doi.org/10.1038/mt.2010.24

10. Parkhurst MR, Yang JC, Langan RC, Dudley ME, Nathan DA, Feldman SA, Davis JL, Morgan RA, Merino MJ, Sherry RM,
Hughes MS, Kammula US, Phan GQ, Lim RM, Wank SA, Restifo NP, Robbins PF, Laurencot CM, Rosenberg SA (2011) T cells targeting carcinoembryonic antigen can mediate regression of metastatic colorectal cancer but induce severe transient colitis. Mol Ther 19(3):620-626. https://doi.org/10.1038/mt.2010.272

11. Maus MV, Haas AR, Beatty GL, Albelda SM, Levine BL, Liu X, Zhao Y, Kalos M, June CH (2013) T cells expressing chimeric antigen receptors can cause anaphylaxis in humans. Cancer Immunol Res 1(1):26-31. https://doi.org/10.1158/2326-6066. CIR-13-0006

12. Scholler J, Brady TL, Binder-Scholl G, Hwang WT, Plesa G, Hege KM, Vogel AN, Kalos M, Riley JL, Deeks SG, Mitsuyasu RT, Bernstein WB, Aronson NE, Levine BL, Bushman FD, June CH (2012) Decade-long safety and function of retroviral-modified chimeric antigen receptor T cells. Sci Transl Med 4(132):132ra53. https://doi.org/10.1126/scitranslmed.3003761

13. Larson SM, Truscott LC, Chiou TT, Patel A, Kao R, Tu A, Tyagi T, Lu X, Elashoff D, De Oliveira SN (2017) Pre-clinical development of gene modification of haematopoietic stem cells with chimeric antigen receptors for cancer immunotherapy. Hum Vaccin Immunother 13(5):1094-1104. https://doi.org/10.1080/21645 515.2016.1268745

14. Hoyos V, Savoldo B, Quintarelli C, Mahendravada A, Zhang M, Vera J, Heslop HE, Rooney CM, Brenner MK, Dotti G (2010) Engineering CD19-specific T lymphocytes with interleukin-15 and a suicide gene to enhance their anti-lymphoma/leukemia effects and safety. Leukemia 24(6):1160-1170. https://doi. org/10.1038/leu.2010.75

15. Budde LE, Berger C, Lin Y, Wang J, Lin X, Frayo SE, Brouns SA, Spencer DM, Till BG, Jensen MC, Riddell SR, Press OW (2013) Combining a CD20 chimeric antigen receptor and an inducible caspase 9 suicide switch to improve the efficacy and safety of T cell adoptive immunotherapy for lymphoma. PLoS One 8(12):e82742. https://doi.org/10.1371/journal.pone.0082742

16. Diaconu I, Ballard B, Zhang M, Chen Y, West J, Dotti Savoldo B (2017) Inducible caspase-9 selectively modulates the toxicities of CD19-specific chimeric antigen receptor-modified T cells. Mol Ther 25(3):580-592. https://doi.org/10.1016/j.ymthe.2017.01.011

17. Wang X, Chang WC, Wong CW, Colcher D, Sherman M, Ostberg JR, Forman SJ, Riddell SR, Jensen MC (2011) A transgeneencoded cell surface polypeptide for selection, in vivo tracking, and ablation of engineered cells. Blood 118(5):1255-1263. https ://doi.org/10.1182/blood-2011-02-337360

18. Paszkiewicz PJ, Fräßle SP, Srivastava S, Sommermeyer D, Hudecek M, Drexler I, Sadelain M, Liu L, Jensen MC, Riddell SR, Busch DH (2016) Targeted antibody-mediated depletion of murine CD19 CAR T cells permanently reverses B cell aplasia. J Clin Investig 126(11):4262-4272. https://doi.org/10.1172/JCI84 813

19. Vogler I, Newrzela S, Hartmann S, Schneider N, von Laer D, Koehl U, Grez M (2010) An improved bicistronic CD20/tCD34 vector for efficient purification and in vivo depletion of gene-modified T cells for adoptive immunotherapy. Mol Ther 18(7):1330 1338. https://doi.org/10.1038/mt.2010.83

20. Philip B, Kokalaki E, Mekkaoui L, Thomas S, Straathof K, Flutter B, Marin V, Marafioti T, Chakraverty R, Linch D, Quezada SA, Peggs KS, Pule M (2014) A highly compact epitope-based marker/suicide gene for easier and safer T-cell therapy. Blood 124(8):1277-1287. https://doi.org/10.1182/blood-2014-01-54502 0

21. Berger C, Flowers ME, Warren EH, Riddell SR (2006) Analysis of transgene-specific immune responses that limit the in vivo persistence of adoptively transferred HSV-TK-modified donor T cells after allogeneic hematopoietic cell transplantation. Blood 107(6):2294-2302. https://doi.org/10.1182/blood-2005-08-3503 
22. Wehler TC, Graf C, Möhler M, Herzog J, Berger MR, Gockel I, Lang H, Theobald M, Galle PR, Schimanski CC (2013) Cetuximab-induced skin exanthema: prophylactic and reactive skin therapy are equally effective. J Cancer Res Clin Oncol 139(10):16671672. https://doi.org/10.1007/s00432-013-1483-4

23. Cartellieri M, Koristka S, Arndt C, Feldmann A, Stamova S, von Bonin M, Töpfer K, Krüger T, Geib M, Michalk I, Temme A, Bornhäuser M, Lindemann D, Ehninger G, Bachmann MP (2014) A novel ex vivo isolation and expansion procedure for chimeric antigen receptor engrafted human T cells. PLoS One 9(4):e93745. https://doi.org/10.1371/journal.pone.0093745

24. Cartellieri M, Feldmann A, Koristka S, Arndt C, Loff S, Ehninger A, von Bonin M, Bejestani EP, Ehninger G, Bachmann MP (2016) Switching CAR T cells on and off: a novel modular platform for retargeting of T cells to AML blasts. Blood Cancer J 6(1):e458. https://doi.org/10.1038/bcj.2016.61

25. Feldmann A, Stamova S, Bippes CC, Bartsch H, Wehner R, Schmitz M, Temme A, Cartellieri M, Bachmann M (2011) Retargeting of $\mathrm{T}$ cells to prostate stem cell antigen expressing tumor cells: comparison of different antibody formats. Prostate 71(9):998-1011. https://doi.org/10.1002/pros.21315

26. Feldmann A, Arndt C, Bergmann R, Loff S, Cartellieri M, Bachmann D, Aliperta R, Hetzenecker M, Ludwig F, Albert S, ZillerWalter P, Kegler A, Koristka S, Gärtner S, Schmitz M, Ehninger A, Ehninger G, Pietzsch J, Steinbach J, Bachmann M (2017) Retargeting of T lymphocytes to PSCA- or PSMA positive prostate cancer cells using the novel modular chimeric antigen receptor platform technology "UniCAR". Oncotarget 8(19):3136831385. https://doi.org/10.18632/oncotarget.15572

27. Bachmann D, Aliperta R, Bergmann R, Feldmann A, Koristka S, Arndt C, Loff S, Welzel P, Albert S, Kegler A, Ehninger A, Cartellieri M, Ehninger G, Bornhäuser M, von Bonin M, Werner C, Pietzsch J, Steinbach J, Bachmann M (2017) Retargeting of UniCAR T cells with an in vivo synthesized target module directed against CD19 positive tumor cells. Oncotarget 9(7):74877500. https://doi.org/10.18632/oncotarget.23556

28. Koristka S, Cartellieri M, Arndt C, Bippes CC, Feldmann A, Michalk I, Wiefel K, Stamova S, Schmitz M, Ehninger G, Bornhäuser M, Bachmann M (2013) Retargeting of regulatory T cells to surface-inducible autoantigen La/SS-B. J Autoimmun 42:105116. https://doi.org/10.1016/j.jaut.2013.01.002

29. Szymczak AL, Workman CJ, Wang Y, Vignali KM, Dilioglou S, Vanin EF, Vignali DA (2004) Correction of multi-gene deficiency in vivo using a single 'self-cleaving' $2 \mathrm{~A}$ peptide-based retroviral vector. Nat Biotechnol 22(5):589-594. https://doi.org/10.1038/ nbt957

30. Arndt C, Feldmann A, Töpfer K, Koristka S, Cartellieri M, Temme A, Ehninger A, Ehninger G, Bachmann M (2014) Redirection of CD4 + and CD8 + T lymphocytes via a novel antibody-based modular targeting system triggers efficient killing of PSCA + prostate tumor cells. Prostate 74(13):1347-1358. https://doi.org/10.1002/ pros. 22851

31. Koristka S, Cartellieri M, Theil A, Feldmann A, Arndt C, Stamova S, Michalk I, Töpfer K, Temme A, Kretschmer K, Bornhäuser M, Ehninger G, Schmitz M, Bachmann M (2012) Retargeting of human regulatory $\mathrm{T}$ cells by single-chain bispecific antibodies. J Immunol 188(3):1551-1558. https://doi.org/10.4049/jimmu nol.1101760

32. Albert S, Arndt C, Feldmann A, Bergmann R, Bachmann D, Koristka S, Ludwig F, Ziller-Walter P, Kegler A, Gärtner S, Schmitz M, Ehninger A, Cartellieri M, Ehninger G, Pietzsch HJ, Pietzsch J, Steinbach J, Bachmann M (2017) A novel nanobody-based target module for retargeting of T lymphocytes to EGFR-expressing cancer cells via the modular UniCAR platform. Oncoimmunology 6(4):e1287246. https://doi.org/10.1080/21624 02X.2017.1287246
33. Stamova S, Cartellieri M, Feldmann A, Arndt C, Koristka S, Bartsch H, Bippes CC, Wehner R, Schmitz M, von Bonin M, Bornhäuser M, Ehninger G, Bachmann M (2011) Unexpected recombinations in single chain bispecific anti-CD3-anti-CD33 antibodies can be avoided by a novel linker module. Mol Immunol 49(3):474-482. https://doi.org/10.1016/j.molimm.2011.09.019

34. Arndt C, Feldmann A, von Bonin M, Cartellieri M, Ewen EM, Koristka S, Michalk I, Stamova S, Berndt N, Gocht A, Bornhäuser M, Ehninger G, Schmitz M, Bachmann M (2014) Costimulation improves the killing capability of T cells redirected to tumor cells expressing low levels of CD33: description of a novel modular targeting system. Leukemia 28(1):59-69. https://doi.org/10.1038/ leu.2013.243

35. Koristka S, Cartellieri M, Feldmann A, Arndt C, Loff S, Michalk I, Aliperta R, von Bonin M, Bornhäuser M, Ehninger A, Ehninger G, Bachmann MP (2014) Flexible antigen-specific redirection of human regulatory $\mathrm{T}$ cells via a novel universal chimeric antigen receptor system. Blood 124:3494

36. Mitwasi N, Feldmann A, Bergmann R, Berndt N, Arndt C, Koristka S, Kegler A, Jureczek J, Hoffmann A, Ehninger A, Cartellieri M, Albert S, Rossig C, Ehninger G, Pietzsch J, Steinbach J, Bachmann M (2017) Development of novel target modules for retargeting of UniCAR T cells to GD2 positive tumor cells. Oncotarget 8(65):108584-108603. https://doi.org/10.18632/oncotarget .21017

37. Koristka S, Kegler A, Bergmann R, Arndt C, Feldmann A, Albert S, Cartellieri M, Ehninger A, Ehninger G, Middeke JM, Bornhäuser M, Schmitz M, Pietzsch J, Akgün K, Ziemssen T, Steinbach J, Bachmann MP (2018) Engrafting human regulatory T cells with a flexible modular chimeric antigen receptor technology. J Autoimmun 90:116-131. https://doi.org/10.1016/j.jaut.2018.02.006

38. Albert S, Arndt C, Koristka S, Berndt N, Bergmann R, Feldmann A, Schmitz M, Pietzsch J, Steinbach J, Bachmann M (2018) From mono- to bivalent: improving theranostic properties of target modules for redirection of UniCAR T cells against EGFR-expressing tumor cells in vitro and in vivo. Oncotarget 9(39):25597-25616. https://doi.org/10.18632/oncotarget.25390

39. Bippes CC, Feldmann A, Stamova S, Cartellieri M, Schwarzer A, Wehner R, Schmitz M, Rieber EP, Zhao S, Schäkel K, Temme A, Scofield RH, Kurien BT, Bartsch H, Bachmann M (2011) A novel modular antigen delivery system for immuno targeting of human 6-sulfo LacNAc-positive blood dendritic cells (SlanDCs). PLoS One 6(1):e16315. https://doi.org/10.1371/journal.pone.0016315

40. Kirschner A, Thiede M, Blaeschke F, Richter GH, Gerke JS, Baldauf MC, Grünewald TG, Busch DH, Burdach S, Thiel U (2016) Lysosome-associated membrane glycoprotein 1 predicts fratricide amongst $\mathrm{T}$ cell receptor transgenic $\mathrm{CD} 8+\mathrm{T}$ cells directed against tumor-associated antigens. Oncotarget 7(35):56584-56597. https ://doi.org/10.18632/oncotarget.10647

41. Ebert LM, Yu W, Gargett T, Brown MP (2018) Logic-gated approaches to extend the utility of chimeric antigen receptor T-cell technology. Biochem Soc Trans 46(2):391-401. https:// doi.org/10.1042/BST20170178

42. Chu F, Cao J, Neelalpu SS (2018) Versatile CAR T-cells for cancer immunotherapy. Contemp Oncol (Pozn) 22(1A):73-80. https ://doi.org/10.5114/wo.2018.73892

43. Wu CY, Roybal KT, Puchner EM, Onuffer J, Lim WA (2015) Remote control of therapeutic $\mathrm{T}$ cells through a small moleculegated chimeric receptor. Science 350(6258):aab4077. https://doi. org/10.1126/science.aab4077

44. Sommermeyer D, Hudecek M, Kosasih PL, Gogishvili T, Maloney DG, Turtle CJ, Riddell SR (2016) Chimeric antigen receptor-modified $\mathrm{T}$ cells derived from defined CD8+ and CD4+ subsets confer superior antitumor reactivity in vivo. Leukemia 30(2):492-500. https://doi.org/10.1038/leu.2015.247 
45. Feldmann A, Arndt C, Töpfer K, Stamova S, Krone F, Cartellieri M, Koristka S, Michalk I, Lindemann D, Schmitz M, Temme A, Bornhäuser M, Ehninger G, Bachmann M (2012) Novel humanized and highly efficient bispecific antibodies mediate killing of prostate stem cell antigen-expressing tumor cells by CD8+ and CD4+ T cells. J Immunol 189(6):3249-3259. https://doi. org/10.4049/jimmunol.1200341

46. Derer S, Bauer P, Lohse S, Scheel AH, Berger S, Kellner C, Peipp M, Valerius T (2012) Impact of epidermal growth factor receptor (EGFR) cell surface expression levels on effector mechanisms of EGFR antibodies. J Immunol 189(11):5230-5239. https://doi. org/10.4049/jimmunol.1202037

47. Valton J, Guyot V, Boldajipour B, Sommer C, Pertel T, Juillerat A, Duclert A, Sasu BJ, Duchateau P, Poirot L (2018) A versatile safeguard for chimeric antigen receptor T-cell immunotherapies. Sci Rep 8(1):8972. https://doi.org/10.1038/s41598-018-27264-w

48. Bachmann M, Chang S, Bernd A, Mayet W, Meyer zum Büschenfelde KH, Müller WE (1991) Translocation of the nuclear autoantigen La to cell surface: assembly and disassembly with the extracellular matrix. Autoimmunity 9(2):99-107. https://doi. org/10.3109/08916939209146128

Publisher's Note Springer Nature remains neutral with regard to jurisdictional claims in published maps and institutional affiliations. 